ISSN 0854-9818

OCCASIONAL PAPER NO. 33

August 2001

\title{
Forestry, Poverty and Aid
}

\author{
J.E. Michael Arnold
}

CENTER FOR INTERNATIONAL FORESTRY RESEARCH

Office address: Jalan CIFOR, Situ Gede, Sindang Barang, Bogor 16680, Indonesia Mailing address: P.O. Box 6596 JKPWB, Jakarta 10065, Indonesia

Tel.: +62 (251) 622622; Fax: +62 (251) 622100

E-mail: cifor@cgiar.org

Website: http://www.cifor.cgiar.org 


\section{CIFOR}

CIFOR was established in 1993 as part of the Consultative Group on International Agricultural Research (CGIAR) in response to global concerns about the social, environmental and economic consequences of forest loss and degradation. CIFOR research produces knowledge and methods needed to improve the well-being of forest-dependent people and to help tropical countries manage their forests wisely for sustained benefits. This research is done in more than two dozen countries, in partnership with numerous partners. Since it was founded, CIFOR has also played a central role in influencing global and national forestry policies.

\section{CGIAR}

The Consultative Group on International Agricultural Research (CGIAR), established in 1971 , is an informal association of nearly 60 public and private sector donors that support a network of 16 international agricultural research centers. The CGIAR's mission is to contribute to food security and poverty eradication in developing countries through research, partnership, capacity building and policy support. The CGIAR promotes sustainable agricultural development based on environmentally sound management of natural resources.

This publication is supported by

Swedish International Development Co-operation Agency (Sida) 


\section{Contents}

Summary 1

$\begin{array}{ll}\text { Defining poverty } & 1\end{array}$

Forests, poverty and poverty alleviation in overview 1

Forest industries and 'the attack on economic

Forest inputs into rural livelihoods $\quad 2$

Poverty, deforestation and biodiversity loss 4

Different patterns of the people/forest relationship 4

Forest dwelling populations $\quad 5$

Agricultural populations living near forests 5

Agricultural populations with agroforestry resources 5

Forest product producers, traders and employees $\quad 5$

Issues arising in forestry aid related to poverty alleviation 5

1. Participatory management of forests 6

2. Smallholder and communal tree growing 7

3. Processing and trading of forest products 8

Potential improvements to the poverty focus of forestry aid 9

1. Linking forestry more closely with rural development $\begin{array}{ll}\text { strategies } & 10\end{array}$

2. Adjusting priorities within forestry assistance 11

3. Improving performance and governance 13

$\begin{array}{ll}\text { Key issues for donors } & 15\end{array}$

$\begin{array}{ll}\text { References } & 15\end{array}$ 


\title{
Forestry, Poverty and Aid
}

\author{
J.E. Michael Arnold
}

\begin{abstract}
Summary
Very large numbers of the rural poor derive some part of their livelihood inputs from forest resources, in different ways and to different extents. For many the dependence on forests is a function of their poverty, because they lack better alternatives. Helping meet their subsistence and survival needs can therefore be as important a role for forestry aid as supporting those able to increase their incomes through forest activities, but needs to avoid encouraging forms of forest dependence that could lock the very poor into continued poverty. Programmes to devolve forest use and management rights to local users have often improved access by the poor, but their impact has frequently been limited by government failures to transfer full or effective rights, and by regulations and actions that restrict access by small producers to formal sector markets for forest products. This has taken the form of the state retaining rights to timber and other valuable components of the resource, of restrictions in favour of biodiversity conservation, of governments being unable in a period of declining budgets for forestry to provide necessary support, and of forest departments and corporations intervening as trade intermediaries and competing producers. In addition, weaknesses in the institutional arrangements for devolved forest management and control have often resulted in transfers favouring the less poor, or outside users. Assistance to smallholder tree growing and commercial activities has also often failed to take sufficient account of the poorer amongst those being targeted. The paper suggests a number of ways in which forestry aid might address some of these issues and become more effectively poverty oriented.
\end{abstract}

\section{Defining poverty}

Poverty has generally been defined as having insufficient food, income, and other inputs to maintain an adequate standard of living, with the latter sometimes being defined to include consideration of quality of life.

This 'welfare' definition of poverty has recently been broadened to recognise the importance of access to assets. Asset poverty is defined as insufficient assets (natural, physical, financial, human, social), or lack of an appropriate mix of assets, to be able to generate or sustain an adequate and sustainable level of livelihood. Livelihood is defined in this connection as comprising the capabilities, assets and activities required for a means of living, and is sustainable when it can cope with and recover from stresses and shocks, and maintain or enhance its capabilities both now and in the future (Carney 1998).

Adoption of this broader definition of poverty can be helpful in understanding the strategies that households pursue in order to sustain their livelihoods. It focuses on five different types of wealth needed for sustainable livelihoods, and gives an analysis of what is possible with a household's existing assets. This contributes to the identification of the possible role of forests and forest products in poverty alleviation, and of how forest based solutions compare with alternative courses of action.

It also draws attention to a number of related dimensions of poverty, and to impediments in the way of poverty alleviation; notably weaknesses in the position of the poor which prevent them exercising options that a resource endowment could make available, and their vulnerability to shocks to their livelihood systems. The recent literature has also pointed to the need to differentiate between different levels of poverty - there usually being pronounced differences between the situations of the moderately poor and the very poor. Poverty is also experienced differently according to social, gender, age and occupational groups (Forsyth and Leach 1998).

\section{Forests, poverty and poverty alleviation in overview}

The main contributions that forests can make to the livelihoods of the rural poor are evident: new areas for crop agriculture and livestock, a range of subsistence products to complement what can be produced from the 
household farm, and sources of income. Programmes to manage forest resources so as to increase or better focus their contributions to development out of poverty have been shaped by prevailing thinking about the broader development process. Forestry development has at different times reflected a focus on forest industry, forestry and rural development, and forestry and conservation of biodiversity.

\section{Forest industries and 'the attack on economic underdevelopment'}

By the early 1960s, development theory and practice were strongly focused on industry-led approaches. The emphasis was on accelerating macro growth by creating a modern industrial sector in the economy, supported by an urban infrastructure and labour force. The industry sector was favoured because demand for industrial products grows faster than demand for food, and it was believed that complementarities among industries meant that growth in one helped others grow as well. The agricultural sector would provide a source of capital and labour for the urban industrial sector, and of low cost food for urban populations, and a market for the products of industry. Rural populations would share in the wealth created in this way through the normal workings of the market economy-the 'trickle down' effect. In short, growth was given priority over equity.

Approaches to development in the forest sector reflected arguments that forest industries had characteristics that enabled them to contribute particularly strongly to industry-led development (Westoby 1962). It was argued that forest products enter widely into the economy and face vigorous demand, and that forest industries have above average growth rates and earn and save foreign exchange, and have strong forward and backward linkages to other industries. It was also argued that their rural location could help bring modern sector skills, jobs and infrastructure to the rural economy, and that the choice of different mixes of capital and labour in many forest industry processes adds to their potential for generating rural employment.

In practice, the positive impacts of forest industries development proved more limited. To be competitive, they had to employ advanced, capital-intensive technology. Dependence on imported capital equipment and process inputs, and high infrastructure costs, meant that many forest industries in developing countries proved to be a drain on, rather than a contributor to, the foreign exchange balance and the economies of those countries (Douglas 1983). Their operation needed skills not available in the rural areas, so much of the employment went to outsiders. The unskilled jobs that they did generate for rural people tended to be limited in number, often temporary in nature, and frequently disruptive of existing, more sustainable, agricultural activities.

As conventionally pursued, forest industry development has consequently not been a major vehicle for the alleviation of rural poverty (Westoby 1978). In recent years various approaches have emerged which attempt to structure and organise formal sector forest-industry operations in ways that provide better access to rural participants (e.g. as sub-contractors or out-growers). However, the principal avenue through which the rural poor have been able to participate in commercial/ industrial growth based on forest resources has proved to be through the small-scale activities of the informal sector, which have owed their growth more to rural than urban/industrial development initiatives.

\section{Forest inputs into rural livelihoods}

The major shift in emphasis towards forestry programmes that directly addressed the needs and possibilities of the rural poor that occurred in the 1970s reflected a broader movement away from development strategies narrowly focused on the urban industrial component of economies. The folly of neglecting agriculture became increasingly evident. It was recognised that agricultural growth was essential if food supplies were to be adequate, and that economic growth was unlikely to be sustained if large parts of society remained impoverished. The focus on wood fuels in forestry programmes in the 1970s reflected the early focus in rural development programmes on meeting the 'basic needs' of the poor. As rural development evolved to encompass first 'food security' and then 'livelihood security', forestry broadened its focus accordingly to address a wider range of linkages with rural livelihoods.

Salient features of the linkages, and about the ways in which they have been evolving, are summarised in Box 1. Very large numbers of rural households in developing countries are still subsistence users of forest/ tree products. Though the share of such products in their livelihood systems may often be declining, and supplies are often coming from managed tree stocks as well as natural forests, forests often continue to serve as an important source - and as a reserve to be drawn on more heavily in difficult times. Access to forest or tree resources can also help rural households diversify their livelihood base and reduce their exposure to risk. Forests can thus form an important safety net for the very poor in times of hardship. 
Box 1. Forest Outputs and Rural Livelihoods ${ }^{1}$

\section{Characteristics of livelihood inputs from forests}

\section{Subsistence and cultural importance}

Forests form an integral part of the social and cultural

framework for forest dwellers.

Forest products supplement/complement inputs of fuel, food, medicinal plant products, etc., from the farm system; often important in filling seasonal and other food gaps, particularly in hard times; forest foods enhance palatability of staple diets, and provide vitamins and proteins.

\section{Agricultural inputs}

Forests provide a starting point for rotational agriculture and protection; on-farm trees also provide shade, windbreaks and contour vegetation; trees/forests also provide low cost soil nutrient recycling and mulch. Arboreal fodder and forage, fibre baskets for storing agricultural products, wooden ploughs and other farm implements.

\section{Impacts of change on forest livelihood inputs}

Likely to weaken, but persists widely in some aspects (e.g. medicinal)

Can become more important where farm output and/or nonfarm income declines. Likely to decline in importance as government relief programmes or new agricultural crops make it less necessary to fall back on forest resources, as incomes rise and supplies come increasingly from purchased inputs, or as increasing labour shortages/costs militate against gathering activities, or divert subsistence supplies to income generating outlets.

\section{Commercial outputs}

Forests help diversify the farm household economy, provide counter-seasonal sources of income, and are a source of income in hard times.

Many products are characterised by easy/open access to the resource, and low capital and skill entry thresholds; overwhelmingly small, usually household based, activities; mainly low-return, producing for local markets, engaged in parttime by rural households, often to fill particular income gaps or needs; limited growth potential, but very important in coping strategies of the poor; often particularly important for women (as entrepreneurs as well as employees).

Some forest products provide the basis for full-time and highreturn activities; usually associated with high skill and capital entry thresholds, and urban as well as rural markets.
Trees can become increasingly important as a low capital means of combating declining site productivity, and a low labour means of keeping land in productive use (e.g. home gardens). But, increased capital availability, and access to purchased products, is likely to lead to substitution by other materials (e.g. by pasture crops, fertilizer or plastic packaging).

With increasing commercialisation of rural use patterns some low-input low-return activities can grow; however, most are inferior goods and decline. Some are displaced by factory made alternatives, and others become unprofitable and are abandoned as labour costs rise; gathered industrial raw materials tend to be displaced by domesticated supplies or synthetic substitutes.

Higher return activities serving growing, specialised demand are more likely to prosper, particularly those serving urban as well as rural markets; an increasing proportion of the processing and trading activity is likely to become centred in small rural centres and urban locations.
Although wealthier rural households within a community may be larger users of forest products, the poorer households usually depend on the forest for a larger share of their overall livelihood inputs. Forest product activities can be particularly important to women because many can be combined with their family and household tasks. Ease of access to the resource and low skill and capital thresholds to commercial forest product activities mean that these can be very important in the coping strategies of the very poor. Though often not accounting for a large share of overall household inputs, these inputs can be particularly important in bridging seasonal gaps, meeting particular needs, helping households tide themselves over longer periods of shortage, and maintaining agricultural productivity.

\footnotetext{
${ }^{1}$ The principal sources of the information on which the Box is based are Cavendish (2000), Townson (1995), FAO (1995), Falconer (1990), de Beer and McDermott (1989), and Falconer and Arnold (1989).
} 
As sources of income, commercial forest product activities have, in principle, important potential to help households move out of poverty. However, many of these low-value, labour-intensive activities have to be abandoned as labour costs rise. Others lose market share because they are 'inferior goods' that cease to be used as incomes rise, or are displaced by factory-made alternatives, by imports or substitutes. Many forest product activities, while extremely important in helping the very poor survive in poverty, thus have only limited potential to contribute to livelihood enhancement.

Others do have the potential to grow and generate increased income but generally require skill and capital inputs, and are therefore less likely to be available to the very poor. Indeed it has been argued that where the poor do have high levels of reliance on forest product activities, this is likely to mean that they are facing persistent poverty (Dove 1993).

\section{Poverty, deforestation and biodiversity loss}

A third area of development thinking that has affected approaches to forestry and poverty alleviation stems from the growing concerns about the conservation of forest biodiversity.

It has been widely argued that rural people overuse, and hence degrade and destroy, forest resources because they are poor and have no viable alternative, and that this progressive erosion of the forest resource contributes to them becoming even poorer. This downward spiral will only be prevented, according to this argument, if the poor are provided with more attractive livelihood options, so that they move away from the destructive use of forests. This led to the development of programmes to introduce new livelihood activities in and adjacent to protected areas that would compensate those living in them for the loss of use, and encourage them to participate in the protection of the resource (Fisher 1995, Wells and Brandon 1992).

In the late 1980s a broader concept emerged which linked forest management to both the conservation and rural development approaches. This stemmed from the argument that harvesting of the forest products that rural people exploit and use is less ecologically destructive than timber harvesting, and therefore provides a sounder basis for sustainable forest management. It was further argued that increased commercial harvesting of nontimber forest products should add to the perceived value of the tropical forest at both the local and national levels, thereby increasing the incentive to retain the forest resource, rather than clear it to use the land for agriculture or livestock. This thesis was interpreted as pointing the way to a form of forest management which could serve both conservation and poverty alleviation (e.g. Plotkin and Famolare 1992, Evans 1993), and led to initiatives to expand and provide markets for more locally produced non-timber forest products.

Subsequently, both the poverty-causes-deforestation and conservation-through-commercialisation arguments have been challenged. For instance, it has become clear that in practice, forests seldom provide sufficient income to sustain the livelihoods of those concerned, and that more intensive use of the resource is more likely to conflict with than support conservation. Nevertheless, this approach has helped focus attention on the potential of non-timber forest products as a source of income for many of the rural poor.

\section{Different patterns of the people/ forest relationship}

The available evidence therefore points to the ability of rural people to directly access and use forest products as the main way in which forest resources impact on rural poverty. Enormous numbers of the rural poor derive some part of their livelihood inputs from forest resources. However, it has become increasingly clear that much of this use is a function of their poverty. Forest outputs are used because they have no alternative, helping them cope with poverty but usually providing little opportunity to escape from poverty. Though there are forest product activities that can contribute to better livelihoods, these generally require levels of skill, and access to capital and markets, that are much less widely available to the poor.

This distinction is important in a number of ways. Many of the rural poor will continue to face extreme poverty for some time, and it is therefore important in identifying and shaping assistance to recognise the critical role that forest resources can play in enabling people to cope with persistent poverty. It also suggests that forest resources may often need to be managed to meet the needs both of those with coping strategies and those needing forest outputs for growth activities. This could evidently be complex; not least because demand from those able to engage in activities that are expanding can erode the position of poorer users. There is widespread evidence of instances where the wealthier and more powerful, able to benefit from increased market demand for forest products, progressively exclude the poorer from access to local forest resources that they draw upon for survival. The importance of these factors varies with the 
availability of alternative options to forest use. This can be linked to other characteristics of their physical, economic and institutional environment. A typology that sets out the main patterns of linkage that are encountered could be characterised in a number of different ways. The one that follows is based on an approach developed earlier within CIFOR (Byron and Arnold 1999).

\section{Forest dwelling populations}

Relatively small numbers of people live in a forested environment. Where they do, they are likely to exhibit a high degree of dependence on the forests, and a homogeneity that enables them to manage the latter collectively as common property. Though such management systems have often been historically stable, they are usually difficult to sustain in the face of growing market and other pressures. Poor infrastructure and access to markets, or to the requisite skills, mean that forest dwellers are seldom well placed to exploit new forestproduct market opportunities. Pathways out of poverty are more likely to be based on agriculture, or migration to wage employment.

\section{Agricultural populations living near forests}

Very large numbers live adjacent to forests, or remnants of forests and woodland, which are available as common pool resources, drawing on them to complement farm outputs and as a component of livelihood diversification strategies. There are often several categories of users and stakeholders, both within and external to the community, with different and often conflicting interests in the resource. Increasing market opportunities can mean growing pressures to privatise product flows, and even the resource and land, disadvantaging poorer households who depend on continued access to forests as common pool resources.

\section{Agricultural populations with agroforestry resources}

With declining access to naturally occurring forest resources, and shifting patterns of availability and allocation of land and labour that favour more use of planted trees, large numbers of farm households are increasing the tree resources on their farm land. This is not an option available to the landless or sharecroppers and many other very small farmers. But for many poor farmers this can provide a low cost means of enhancing site productivity, reducing exposure to risk, and meeting household needs for tree products. For households not dependent on the land for food production, tree crops can also become a source of income and capital.

\section{Forest product producers, traders and employees}

In nearly every country where such information exists, small-scale forest product activities are found to be among the three largest categories of non-farm rural commercial activity, in terms of the numbers of people engaged in them (Liedholm and Mead 1993, FAO 1987). Small-scale forest product processing and trade of forest products thus make up an important part of the non-farm component of the rural economy, and are open to the landless as well as small farmers. There is strong participation by women in these processing and trading activities. However, many activities exhibit the growth limitations discussed earlier. Wage employment in largerscale forest industry, and in plantation projects, can also provide a valuable additional income-generating option for the poor, but often proves to be available for only limited periods of time.

These categories are not mutually exclusive. Many farm households draw supplies of forest products both from nearby forests and from their own tree stocks. Substantial numbers also have household members involved in processing or trading as well. However, management and use of common pool resources, tree growing on farms, and production and trade of forest products, involve quite different technical, governance and other issues, and therefore require different kinds of intervention and assistance. They are therefore likely to be addressed through different forms of forestry aid.

The discussion also shows that the majority of those who can benefit from forest products live outside forests; they live in predominantly agricultural landscapes, and for many of them the forest products they use come as much from the farm as the forest. Forestry's role in poverty alleviation is thus large only if we define 'forestry' to encompass sources of forest products outside as well as inside forests.

\section{Issues arising in forestry aid related to poverty alleviation}

Forms of aid to forestry that have had a direct or indirect aim of alleviating poverty have been concentrated in three areas:

1. increased participation by local users in forest management in order to make the latter more responsive to their needs, and to increase the benefits flowing to them;

2. support to tree growing on farms; and 
3. exploiting the income-generating opportunities that production and trade in forest products in the non-farm rural economy can provide ${ }^{2}$.

\section{Participatory management of forests}

\section{New schemes with mixed results}

Probably the main area where aid programmes have attempted to target the rural poor has been in the paradigm shift towards transferring more of forest management to the local level. Recognition that forest management needs to be 'participatory' has moved steadily from passive interpretations of participation, requiring little more than that those affected be informed of decisions made about them, to more substantive measures involving local people in decision-making, and increasingly in the control and management of the forests they draw upon.

Given that most local use of forests is as common pool resources, much attention has centred on the potential for control and management by user groups and communities as common property. However, most of what has been emerging in practice has taken the form of joint management between the state and local user communities, rather than devolution of responsibility solely to the latter. The arguments in favour of joint management have become more prominent as it has become apparent that often, user communities and institutions are unable to take on responsibility for control and management unaided. Joint management has also been favoured by governments because transferring management and protection responsibilities to the community level can help offset the reduction in the budgetary resources available to forest departments. However, such forms of local management run the risk that they result in the state continuing to exert too great a measure of control.

Experience with participatory management has been variable. Many programmes have resulted in a greater degree of involvement of rural users, but this has not always been in ways that have benefited the poor. Many earlier interventions were based on an insufficient understanding both of the circumstances under which collective management is appropriate, and of the realities of the present circumstances of the rural populations involved. Experience has also exposed serious problems in the ways in which governments have pursued devolution of responsibilities for forest management.

\section{Failure to transfer effective authority}

Participation has been primarily a donor objective, not always shared by governments of rentier states without much incentive to stimulate the rural sector (Brown 1999). In practice, policies and programmes that actually empower local people to make decisions and set objectives, or at least to have a genuine role in decisionmaking, are rare (Agrawal and Ostrom 1999). Devolution has been pursued in forestry where it has been seen as a less costly strategy for pursuing sustainable forest management in a period when central budgets are shrinking. This is reflected in the large number of joint management programmes that insert a significant forest department presence into the collaborative agreements and institutions.

The result has often been 'participation' that is more apparent than real. 'Participatory' mechanisms emerge which enable forest departments to create local partners that become their proxies, rather than representatives of local users able to challenge their actions when necessary (Hobley 1996). People may acquiesce in such changes, because they have no choice to do otherwise, but they are not empowered by them (Ribot 1999).

In addition, too much of decentralization within forestry is effected by administrative order or permit, rather than legislation. The rights and authority provided in this way can be withdrawn or, if challenged, are unlikely to be upheld in law. This further weakens the position of rural people in their dealings with the state (Bruce 1999).

\section{Restrictions on rights granted to the poor}

Another limitation results from the widespread practice of transferring only limited rights, notably the widespread exclusion of rights over timber and other components of commercial value (Agrawal and Ribot 1999). Related to this is the practice of restricting participatory forestry to degraded or poorer areas of forest. Though some programmes have attempted to upgrade the potential of the latter, it has proved difficult to devise more productive forest management systems that avoid disadvantaging the poorest. One example is fuelwood headloaders who had to give up their previous gathering activities, but do not share proportionately in the new benefits (Hill and Shields 1998).

Revenue sharing agreements, taxation, and regulations requiring local producers to sell their produce through state marketing bodies similarly limit the benefits available to the poor, and reduce their incentives to

\footnotetext{
2 The discussion in the following sections draws heavily on material developed for a review of community forestry prepared for FAO (Arnold forthcoming).
} 
participate in sustainable forest management. Access to potential increases in benefit flows is also often limited by regulatory constraints associated with conservation of the resource. As one study of experience with 'protected area' projects has reported, 'unambiguously successful and convincing examples where local people's development needs have been effectively reconciled with biodiversity conservation remain difficult to find'. (Wells and Brandon 1992).

\section{Ineffective and inequitable local institutions}

Implicit in much of the pursuit of participatory community forestry has been the assumption that the conditions of homogeneous communities that in the past often favoured collective management still exist, or can be recreated (Campbell 1990). In many situations the reality is communities that are internally differentiated by wealth, power, class, gender and ethnic identity, and unlikely to share a consensus view about how the forest should be managed and used. There can be conflicting interests among the poor between pastoral and settled users, between the landed and the landless, and between genders. The needs of the poor for continued access to a common pool biomass resource to help sustain predominantly subsistence-based coping strategies can increasingly conflict with the interests of the better-off and outsiders. The latter wish to privatise forest output flows in order to benefit from the opportunities that increasing commercialisation of forest products presents, or seek to privatise the land and put it to non-forest uses.

All too often, local institutions have proved unable to cope with the complexities arising from conflicting claims on the resource. The result is then likely to be that control over access to the forest resource is captured by the more powerful within the community - to the detriment of the poor. This is all the more likely when the process of devolution transfers authority to local leaderships who pursue agendas that focus on their own rather than the community's interests. Sometimes, authority is transferred to local bodies that are in practice appointees or extensions of the central government, and consequently more responsive to the latter than to the people they represent.

Securing the rights of access of the poor to forest product resources in such fractured and often conflict-ridden communities has proved problematic. There is growing recognition that different approaches are needed in order to address these institutional issues, and of the limitations of the 'community' as a vehicle for empowering the poor. However, it is not at all clear at present which of the various alternatives that have been put forward could be more effective (FAO 1999).

\section{Smallholder and communal tree growing}

Programmes to encourage and support local level tree growing - in order to reduce pressures on remaining forests, restore forest cover, and enhance their access to benefits - have generally had disappointing results. Many have resulted in little additional planting taking place. Where it has occurred it has often been in forms that produced results other than those planned and hoped for. To a large extent this reflects a failure to recognise the spontaneous responses that rural people deploy in order to cope with fuel and other tree product shortages, and insufficient recognition of the actual role of planted trees in farm systems.

The role of trees in farming systems needs to be assessed in the context of farm household livelihood needs and strategies, rather than as a part of forest resources. Small farmers generally deploy a variety of tree species, usually with preference for those that produce several outputs, tailored to their farm and household needs. Interventions narrowly focused on just one tree-related issue, such as fuelwood supplies, thus tend to:

- encourage tree growing where trees are not an appropriate component of the farm household economy, or

- induce growing of inappropriate trees, or

- require changes in the institutional or social framework that could not be achieved in connection just with tree growing (Dewees 1997).

The focus of many forestry extension programmes for farmers on timber and pole species, and on the growing of such species in woodlots, has also tended to be counterproductive. Woodlots on common land deprived previous users of access to the previous sources of fodder, fuel, etc., and created a resource from which the poor could obtain little if any benefit. The choice of species better suited to market rather than subsistence uses was at variance with small farmer needs. Trading in tree products by small farmers usually develops incrementally:

- as local markets for tree products emerge,

- as shortages develop,

- $s$ increasing demands on the time of household members leave less time for gathering what is needed to meet household needs, and

- as rising cash incomes allow more purchasing rather than gathering or growing.

The growing of trees as cash crops for urban and industrial markets is more likely to be practised by farmers in areas where the process of agrarian transition 
has evolved further towards greater involvement in commodity markets, and an entrepreneurial approach to agriculture based on cash crops (Arnold and Dewees 1997). Evaluation of the extensive experience of farmer tree growing in India showed that eucalyptus farming proved to be a viable option mainly for wealthier farmers who had more land, had more assets, faced shortages of labour and problems of supervision, and had diversified sources of income (Saxena 1992).

Another common weakness has been a focus on subsidising tree establishment by farmers rather than matching tree growing to demand, leading to supply/ demand imbalances and poor prices. There is evidence of planting subsidies in some programmes in India leading to undesirable distortions in land use, such as displacement of sharecroppers and grazing, and reduction in small farmer subsistence production of food crops to the point where household food self-sufficiency levels could be adversely affected. There are also concerns that farmer tree planting in China encouraged by low cost loans from the World Bank will prove to be unsustainable as these concessionary funding sources are withdrawn.

A further weakness in past programmes, in terms of their providing the rural poor with access to tree growing as a source of income, has been the lack of progress in removing constraints on access to markets that many governments place in the way of private production for sale. Private producers are frequently subjected to costly controls on the harvesting, transport and sale of wood and other forest products to protect against illegal or excessive felling, or to control competition with production from state plantations and forests, or to capture some of the value for the state.

Such weaknesses in farmer tree growing support programmes were most pronounced during the focus in the 1970s and 1980s on filling perceived fuelwood 'gaps'. Some better focused, more livelihood-oriented farm forestry programmes have been developed subsequently. Recently there have also been a limited number of projects to exploit the potential to provide smallholder tree growers with secure market outlets, and support services, as out-growers linked to particular forest industry plants.

Nevertheless, there are signs of a return to the earlier, less discriminating approach to smallholder tree planting in the renewed recent enthusiasm for plantations to help alleviate erosion of biodiversity resources, and to make productive use of 'fragile' lands (e.g. World Bank 2000). This has been accompanied by a revival of interest in developing schemes to enable farmers, or the landless, to grow trees on public land. However, most have focused on encouraging participants to use the land just for trees, rather than trees and crops (sometimes because of the perceived risk that crops would strengthen farmer claims to longer term tenure of the land). But the intermittent nature of income flows from tree growing makes it an unsuitable basis for livelihood security for the poor. Such schemes are therefore more suitable for those who have other land on which they can grow food crops, or other sources of income to meet ongoing needs.

Tree planting on common or other public land can create other problems for the poor if the land to be allocated previously had other uses. If there is insufficient cultivable land available to be able to grant leases to all the landless in the community, problems of choice of participants arise. And those who do not benefit from the scheme are left with reduced access to the common pool resources on which they have depended for grazing, fuel, etc.

\section{Processing and trading of forest products}

There is growing evidence that the numbers engaged in small enterprise processing and trading of forest products far exceed those in industrial forestry and forest industry. In Zimbabwe, for instance, surveys indicated that in 1991 there were an estimated 273,000 engaged in small woodworking, woodfuel and cane activities and 16,000 employed in forest plantations and industries (Arnold et al. 1994).

\section{Small-scale enterprise activities}

The large numbers already engaged in some measure of artisan or small enterprise income generating forest product activity, and the ease of access for many of the rural poor to many of these activities, makes this potentially an important area for assistance. However, forestry programme interventions to date have tended to focus on improving access to raw materials, with relatively little attention to access to markets, marketing, or matching supply to demand. Such support as small producers and sellers have had access to has tended to come from programmes aimed at small enterprise activities as a whole.

Because they give priority to conservation objectives, many governments have set in place forest and environmental policies and regulations designed to limit rather than encourage private production and sale of forest products. Restriction of output by means of regulations is often favoured because it is seen as easier than controlling forest use on the ground (Dewees and Scherr 1996). Government regulations, and forest department practices, can also exist that restrict 
smallholder involvement in the more valuable components of forest production and trade in favour of the state or industry. Other constraints that small producers can face include prices of some products, such as fuelwood, that are kept artificially low to favour urban consumers, and trading structures that favour large producers such as industry and forest departments. There is a danger that, by hindering small producer access to the market in these ways, governments may inadvertently be interfering with the shift from subsistence to the market economy.

In pursuit of the 'conservation by commercialisation' approach, a number of initiatives have been launched, mainly with NGO support, to encourage trade in particular forest products, generally for industrial or niche export markets. However, such product trades have often proved to be susceptible to change in market requirements, to domination by intermediaries, and to shifts to domesticated or synthetic sources of supply, and few have proved to be sustainable. Consequently they can expose rural households to risk, particularly where the trade has encouraged people to move away from more diversified and less risky agriculture-based livelihoods, as has happened with some of the extractive product trades from the Amazon region (Browder 1992).

\section{Forest industry and rural populations}

Although the numbers engaged in larger, formal sector, forest industries remain small, recently a number of factors have encouraged the latter to form stronger links with rural populations in their vicinity. These developments include the trends towards privatisation, devolution of more rights over forest resources to rural communities, and the emergence of on-farm tree stocks as an increasingly important part of the wood and fibre supply total (Mayers 2000). The result has been a limited, but growing, move towards forms of partnership arrangements between companies and farmers and user groups. This has included subcontracting of wood and fibre production to 'outgrower' tree farmers, and joint ventures with communities with appropriate resources in order to generate income from ecotourism and wildlife management (e.g. CAMPFIRE in Zimbabwe).

Partnerships of this nature that provide access to credit, extension, markets and new skills have sometimes enabled co-operative type arrangements to emerge that can increase their bargaining position, and even their participation in some of the benefits from downstream processing and trading ${ }^{3}$. In Mexico, strong support in the $1980 \mathrm{~s}$ from a government pursuing rural development, and assistance from donors, enabled community (ejido) organisations in a forest-rich zone to develop their own logging and harvesting enterprises, replacing parastatal and private timber concessionaires. Incomes were raised and forest loss was slowed down. However, market liberalisation subsequently led to the withdrawal of subsidised support and extension services and this, together with increasing competition due to the North American Free Trade Agreement, put these operations under increasing pressure. Only the largest and best endowed were able to stay in business - as fully commercial rather than communal entities. Communal controls over forest use were weakened, the numbers of the poor benefiting from the forests were reduced, and pressures to privatise and convert communal forest areas increased (Taylor and Zabin 2000).

Another mechanism for channelling some of the monetary benefits from industrial forestry to rural communities with rights to the resource being exploited has been through payments to them. This has long been the situation in principle in many areas, but in practice it has often been neglected. Another disadvantage has been that, where community leaderships are not responsive or accountable to their members, the poor are unlikely to see much benefit from any payments made.

\section{Potential improvements to the poverty focus of forestry aid}

The discussion in this section is based on the perception that there are two basic pathways in which aid to forestry might become more effective in mobilising the potential of forestry to contribute to poverty alleviation. One is to harmonise what is attempted in forestry more closely with what is happening in other sectors, and to recognise the implications of broader changes such as market liberalisation and structural adjustment for rural development. The second is to improve the focus and effectiveness of poverty-related interventions at all levels within the forestry sector, based on a better understanding of what forestry can and cannot actually do to alleviate poverty. This section closes with a discussion of how an improved performance and governance framework can help enhance pro-poor benefits within each of the programme areas sketched in the Issues section.

\footnotetext{
${ }^{3}$ E.g. the South African Wattle Growers Union, set up originally by larger growers but now fully accessible to small farmer growers, which has developed its own processing plants as well as providing loans, training and an extension service.
} 


\section{Linking forestry more closely with rural development strategies}

Most of the linkages between forestry and rural poverty are closely linked with what is happening in agriculture and the rural economy. It is therefore important to recognise the possible impacts on forestry that such macro shifts as market liberalisation are bringing about in agriculture. For instance, this concerns the shift from public programmes to market measures, and consequent impacts on such components of rural development as infrastructure and transfer of technology that have until now been the responsibility of the public sector (Mellor 2000).

Forestry aid programmes could also usefully be more closely aligned with the component parts of rural development strategies and programmes. This can have a number of dimensions, which are discussed further below in terms of the three main thrusts of rural development:

- adapting forestry interventions to take account of changes being introduced in agriculture and the rural economy,

- exploiting opportunities that rural development interventions create for forest-based activities, and

- ensuring that information about adverse effects that non-forest changes could have on the forest-based poverty situation is taken into account.

\section{Agriculture-based development}

Features of agriculture-led development which are likely to constrain, or even reduce, the role of forests and forest outputs include the following:

- In areas where rural development continues to be driven by expansion of the area under cultivation, the potential for increased forestbased contributions to rural livelihoods is likely to be very limited, or even negative.

- Land titling to promote private tenure on farm land, on the grounds that this would stimulate agricultural productivity, may reduce access to resources that poor people previously obtained under the systems of overlapping and interpenetrating rights. These have been common, in particular, in parts of Africa (Neumann 1996).

- Adoption of agricultural technologies, such as tractor cultivation, that encourages the removal of trees in agricultural landscapes.
Forest and tree components will often become more important where changes in agriculture favour greater reliance on agroforestry. This can happen where:

- Changes in the availability of land, labour and capital favour tree crops, e.g. in multi-storey 'home gardens' that increase land productivity, as low input land uses where labour is the limiting factor, or as low cost inputs into farm systems (e.g. in place of purchased fertiliser).

- Growth in agricultural incomes leads to increasing local commercialisation of subsistence goods such as fuelwood and other forest products.

- Improved rural infrastructure gives farmers greater access to markets for forest fruits and other products of trees that can be grown as part of farm systems.

\section{Expanding non-farm rural activities}

The growing importance of non-farm rural activities as a source of rural household income, and the significant share of the non-farm total accounted for by forest product activities, make this one of the most important vehicles through which the forest sector can contribute to poverty alleviation. This impact should be enhanced by matching support interventions to demand, and to factors that enable the poor to participate in the more profitable activities:

- Interventions are likely to be more effective if they are directed to types of forest product activity involving large numbers of people. The very large presence of small-scale activities producing and selling forest products in rural areas reflects the fact that demand for most of this output is also rural (FAO 1987). Large increases in the demand for smallholder and small enterprise commercial activities in the forest sector are therefore likely to occur where the agricultural sector is buoyant and agricultural incomes are growing.

- The key factors determining ability to successfully engage in processing and trading have been shown to be links to markets and access to necessary skills. Support for processing and trading of the more profitable and sustainable forest product activities should thus be focused on areas where improved access to education and infrastructure enable people to take advantage of market opportunities.

- Recognise the importance of simple, low-input and low-output activities in the coping 
strategies of the very poor, and of their role as a 'safety-net' for those experiencing or likely to experience hard times. However, avoid locking people into activities without growth prospects once more attractive livelihood activities emerge or can be located - it can then be more useful to help people move into other, more rewarding activities.

\section{Out-migration}

Migration away from forest areas may be the only alternative for some of the very poor in economically stagnant situations for whom no viable local alternative becomes available when the forest product activities on which they depend decline. It may also be the only option for many when privatisation removes their access to the common pool forest resources on which they draw.

Conversely, migration from agricultural areas is the main cause of the tightening supply of labour on farms, which is a major factor accounting for increased tree growing by farmers. Areas experiencing continuing outflows of labour could therefore be expected to display increased opportunities for farm forestry/ agroforestry. However, this linkage suggests that, should there be renewed inflows of labour in to rural area, or of capital for labour-saving technology, then the shift in land use towards more tree cover could be reversed.

\section{Adjusting priorities within forestry assistance}

If the objective of poverty alleviation is to be given more emphasis within forestry, it could be necessary to rethink priorities and strategies related to a number of dimensions of the forest sector.

\section{Coverage of 'forestry' assistance}

The outline immediately above makes it clear that the greater part of rural poor populations that benefit from 'forest' products are located outside forests as they are normally defined. As discussed earlier (and documented in Wunder 2001), their location and range of available options are likely to mean that forest-based activities are unlikely to figure largely in paths out of poverty for those living in forests. Predominantly agricultural populations able to access forests, tree stocks outside forests, and trees on farms, and able to respond to market opportunities, are more likely to be able to benefit. If forestry assistance is defined widely to encompass all tree stocks, and activities based on them, it is therefore more likely to be able to contribute significantly to poverty alleviation than if it is confined just to forests and forest-dwelling people.

\section{Differentiating between the very poor and the moderately poor}

Though most rural households are poor in absolute terms, there are considerable variations in levels of wealth within the total of the rural poor, even at the level of individual communities. This usually means that only the better endowed, or politically more powerful, are able to take advantage of the more rewarding forest product opportunities available. Moreover, their advancement is all too often at the expense of the poorer, who may easily find themselves excluded from access to resources they rely upon. It will therefore seldom be sufficient to provide assistance simply to the poor. If the purpose is to help the poorest as well as those better able to benefit from assistance, care will have to be taken to structure it in ways that benefit the former as well as the latter.

\section{The balance between poverty alleviation and conservation}

The concerns with biodiversity conservation that have shaped so much of assistance to forestry, including participatory forestry, have been primarily concerns about global conservation values. They reflect predominantly northern concepts and donor preoccupations and, as was discussed earlier, have often acted as a constraint on the pursuit of forest uses that can alleviate poverty. If greater emphasis is to be given to the latter, it will be necessary to take account of the arguments for a revision in the approach to conservation. These include:

- Forest degradation and removal are not necessarily a consequence of poverty. They can be as readily precipitated by rising incomes. In addition, the actions of the poor often conserve rather than overuse the resources they manage. Therefore approaches to sustainable forest management should not be based on assumptions of a mutually reinforcing 'downward spiral' of poverty and forest degradation, that can only be halted by limiting or preventing use of the forests by the poor.

- Assumptions about linkages between human activity and landscape change also need to be revised. Much of what might be considered by ecologists and foresters to be degradation or depletion of a forest resource can be considered to be transformation and even improvement of the resource by those depending on it for inputs into their livelihood systems (Leach and Mearns 1996). 
- There is a need for greater appreciation that the poor experience their own environmental problems, which need to be addressed separately from environmental policies seeking to satisfy concerns about global values. To address these local concerns there is a need to move away from macro scale approaches and policies to a more situation specific focus, reflecting the protective mechanisms that local users themselves adopt, and the attributes of a resource that they value and seek to conserve (Forsyth and Leach 1998).

- Tropical rainforests are more robust and able to absorb and recover from use than has usually been acknowledged, and do not need to be protected against other uses to the extent that has been attempted (Sayer 2000).

- As a much larger part of the remaining tropical forest genetic resource exists in managed landscapes than in protected areas, it could be more logical to focus more of the conservation effort on sustainable management of what is in use. Many of these locally managed resources have a high measure of biodiversity (Halladay and Gilmour 1995).

It needs to be stressed that these arguments do not advocate downgrading the importance of biodiversity conservation. The concern is to better focus the approach to conservation. In recognition of the importance of forest uses to poverty alleviation, conservation objectives for forests of value to local people could appropriately shift from a predominantly protective orientation towards encouraging sustainable systems of producing livelihood benefits in as 'environmentally friendly' a way as possible (Freese 1996). For example, one may encourage options in Southeast Asia that maintain a patchwork or mosaic of agricultural and agroforestry systems which, though less species rich than forests, preserve much more biodiversity than the alternatives of plantations or clearance to crop agriculture (Noordwijk et al. 1997).

\section{The shares of the state and the rural poor in forest benefits}

One of the more fundamental policy issues that many governments need to address is their competition with smallholder and community producers for a share of the economic benefits to be obtained from forest outputs. Governments impose taxes and other charges and costs on the latter. In addition, while providing support to local producers through one part of the forestry assistance programme, they constrain and compete with them through the industrial forestry component of forest department activities. In the short term the scope for improving the situation probably lies mainly in removing or relaxing regulatory provisions that reinforce the structural and scale advantages that the state possesses as a producer of many forest products. The relationship between forest departments and small local producers could also benefit from separation of the regulatory functions of the former from involvement in forest management and delivery of support services.

A logical longer-term solution would be to phase out state production in those markets where smallholder production has a comparative advantage. This would also contribute to meeting a more fundamental concern that has been raised (e.g. Dove 1993); namely that the potential for the rural poor to benefit will continue to be limited as long as they are unable to participate in the more profitable and dynamic product activities.

\section{Conflicts between welfare and market liberalisation objectives}

Policies of market liberalisation and structural adjustment have clearly been one of the determining influences on the way participatory forestry has evolved in recent times. The accompanying goal of devolving away from government any activity that could be more effectively performed by others has been one of the driving forces behind the transfer of responsibility for forest management and control to the local level. At the same time, the downsizing of government budgets available for forestry can reduce the capacity of forest departments to provide necessary support to the new structures, or to adequately continue to perform functions that need to stay in the public domain. However, it is a mistake to assume that participatory forestry is necessarily a low cost route to sustainable forest management-it needs adequate support, which may mean more rather than less state involvement if the poor are not to lose out (e.g. in regulation, conflict mediation, and technical support).

Another impact of such macro economic and policy change has been the acceleration of the process of exposing community level producers of forest products to market forces. This can create additional opportunities to generate income and also heighten pressures on local institutions attempting to manage a resource as common property. The latter can cause a breakdown of collective mechanisms for exclusion and control, and the effective privatisation of the more valuable product flows by those best able to take advantage of the market opportunities.

The likelihood is, therefore, that without countervailing measures, market liberalisation will accelerate the process of communal forest resources passing from collective to individual or corporate control. Indeed, privatisation of 
common pool resources features increasingly as a policy measure in contemporary literature about the management of natural resources. However, many of the poorer users will be left worse off by such a change. Forests as common pool resources constitute an essential safety net for the poor, and for many its importance is likely to increase as they are subjected to increasing pressure from market forces. More attention needs to be paid to the task of ensuring continued collective control of local forest resources where this continues to be needed for equity (and environmental) reasons.

\section{Improving performance and governance}

This penultimate section of the paper looks at ways in which the poverty alleviation impact might be enhanced by improved performance within each of the three programme areas examined in the section on issues that have arisen in past and ongoing aid interventions.

\section{Participatory management of forests}

It has proved much more difficult than expected to bring about the effective and equitable transfer of authority and power. To be effective, empowerment needs not only to establish or recognise the rural poor's rights of ownership or use, but also needs to enable the recipients to exercise their authority and rights. Failure frequently results less from people's lack of institutionally grounded claims on a resource, than from their incapacity to pursue these claims effectively against more powerful actors (Forsyth and Leach 1998).

This requires a greater commitment to ensuring that these rights are entrenched in appropriate legislation and regulations, that mechanisms exist to implement them, and that these mechanisms function properly. Equally importantly, it needs forms of governance for common pool resources that can address the weaknesses in many existing co-management systems that were outlined earlier.

It has become increasingly clear that community forestry can encompass a complex of different interests both within the local user community and among multiple stakeholders with some claim on the resource. Hence, attention has shifted towards more 'pluralistic' approaches and mechanisms that are designed for conditions in which two or more groups, principles, sources of authority, etc., coexist. A number of techniques are evolving to address the analytical and operational challenges that accommodating multiple interests raise in forestry ('stakeholder analysis', the '4Rs' approach, the 'environmental entitlements' approach, 'adaptive management', better use of 'social capital', etc.) (Vira et al. 1998). Though such innovative approaches offer promise, not enough experience of applying them has accumulated yet to allow conclusions to be drawn as to what will succeed.

Concerns have been raised that existing organizational mechanisms could be dismantled or cease to function without new systems of coordination and collaboration taking their place (FAO 1999). Given the political weakness of many local user populations, there is thus a danger that they will be unable to participate in an equitable manner. This possibility has caused some concern that the current enthusiasm for multiple stakeholder systems of local forest management, that require the weaker to negotiate with the more powerful, could be more an expression of 'outsider' conceptions than a realistic way of achieving a more equitable and effective involvement for local users. There appears, therefore, to be a need for more research into pluralistic systems of co-management that really do function effectively and equitably, and for pilot testing of those that show promise.

There is another area where progress is being held up for lack of information about workable solutions. This reflects difficulties in identifying management prescriptions that enable user groups to change forest use and control in ways that increase productivity, and put management on a sustainable basis, without disadvantaging the poorest and usually most heavily dependent. As was noted earlier, it is those, like fuelwood headloaders, who are called upon to give up their practices in order to allow a more productive use of the resource, who usually benefit least from the new or additional production when that becomes available.

\section{Smallholder and community tree growing}

There is a need for interventions to be based on a better understanding of the factors that define when smallholder commercial tree growing is and is not appropriate for the poor. Within such a framework, there are a number of ways in which support to tree growing by farmers can be made more effective, and consistent with small farmer needs and possibilities (Current et al. 1995, Arnold and Dewees 1997):

- More attention should be paid to matching production with demand. For the bulk of farmers for whom farm trees serve a mainly self-sufficiency role, support should focus on helping them move forward incrementally, by providing information about unfamiliar species and planting configurations, and access to a wider menu of species to plant. 
- Production for the market should be encouraged by improving access to markets, and ensuring equitable prices, rather than by subsidising planting. This calls for removing or alleviating constraints caused by costly controls on the private harvesting, transport and sale of tree products, by subsidised competition from state forests and plantations, and by controlled prices for products such as fuelwood.

- Where costs of establishment or husbandry are constraints, the use of credit and measures to reduce costs (such as staggered planting and interplanting with crops that produce intermediate yields) can help avoid distortions arising from subsidies.

Tree out-grower arrangements, and some other forms of contractual agreements, can provide important links to markets and support for farmers, but care needs to be taken to ensure that they are targeted at those able to benefit from them. Situations under which tree outgrowing can be appropriate for smallholders can be where they have sufficient annual income from other sources to secure their ongoing needs, and land which they can use for trees that is not needed for food crop production or for other basic needs. Tree growing is likely to be an attractive option in these circumstances where the features of an assured market and access to technical advice and inputs make tree crops a more stable source of income than alternative uses of the land. These features, and the probable need to have title to their land in order to be eligible for a loan, indicate that tree outgrowing is unlikely to be feasible for very small or poor farmers. It is more likely to be appropriate to the moderately poor.

Programmes to encourage contract planting by smallholders on public lands also need to make sure that they target those for whom the intermittent cash flows that tree crops provide are compatible with their livelihood needs. It is also important to ensure that changing the use of public land does not adversely affect poor prior users of the area (e.g. those who used it as a source of fuelwood and fodder).

\section{Processing and trading of forest products}

The very large numbers of people who succeed in setting up new small-scale commercial forest product activities suggest that in general there is little need for measures to attract new entrants. However, high rates of attrition, particularly amongst new enterprises, indicate the need for interventions to encourage entrants to concentrate on the more viable and sustainable kinds and levels of activity. The fact that the poorer of those engaged in generating income from forest products activities tend to be concentrated in low-return product activities, with poor prospects, presents particular issues. Encouraging participation in the production of products already facing saturated markets is likely to result at best in redistribution among the poor (Hazell and Reardon 1998). In addition, it could mean that participants are prevented from moving into alternative activities with better livelihood prospects. It may therefore be more fruitful to help people move into other, more rewarding fields of work, which may in many cases mean moving out of forest product activities.

As was noted earlier, the main factors likely to enable the poor to move into the more profitable and dynamic areas of forest product activities are location relative to markets and ability to acquire the necessary skills. The main form of useful support, access to micro credit, is likely to come from generalised small enterprise programmes. However, there are also a number of measures within the forest sector that can be important in securing a level playing field for small producers and sellers.

- Smallholder and artisan production and trade of forest products needs a regulatory environment that does not discriminate against this category of production and trade. In this connection, recent moves to require small producers to adhere to product certification requirements must be of some concern. A review of timber certification for ITTO has shown that this places particular burdens on small producers (Simula and Ghazali 1996). Though it could give some better access to niche markets, imposing certification requirements on some non-timber forest product trades could prove even more onerous for many small producers and traders.

- Other possible biases in favour of state and larger scale formal sector forest industry producers to be removed include protection and subsidies for industrial capacity, competing with small producers (as happened with rattan manufactures in Indonesia), and raw material allocation practices by forest departments favouring large users.

- Constraints on access to markets for particular forest products need to be removed or reduced. Producers may be obliged to sell to government marketing bodies, or to traders to whom concessions have been granted. Private producers of non-timber forest products, like 
farmers producing wood, are also often subjected to costly controls on the harvesting, transport and sale of their products.

In part, this entails paying more attention to the balance between the formal and informal sector components of forest product production and trade. In addition to ensuring that conditions that allow large companies to compete unfairly with small producers are not allowed to emerge, more attention should be paid to exploiting their complementarities, and the potential for small, labour intensive enterprise activities to benefit from links with larger companies. For aid programmes this could mean focusing on improving the bargaining position of smallholders and rural communities in such partnerships.

Where, as must often be the case, the scope for competitive participation as producers in technologically complex and capital intensive forest industries does not exist, attention should focus on enabling rural stakeholders in the resource to benefit financially, as shareholders or joint venture partners. However, for this to benefit the poor will require institutional mechanisms that channel and allocate such benefits equitably.

\section{Key issues for donors}

Particular issues that donors might need to consider include the following:

- Help mitigate undesirable impacts on the poor of globalisation and market liberalisation in the forest sector (e.g. privatisation of forest resources that the very poor need to continue to be able to access as common property).

- If poverty alleviation is to become a main objective for forestry, determine how widely forestry programmes should extend across tree resources outside forests in order to address the poverty reduction potentials that tree growing by farmers and small enterprise activities can offer.

- If, on the other hand, forestry programmes are to remain focused on forests, recognise that the main thrust should be to enhance the survival and safety net roles that forests can play for the very poor.

- Revise donor approaches to conservation to make the present focus on global values more responsive to local environmental needs and possibilities, and better attuned to the priority of poverty alleviation.
- Continue to encourage governments to effectively empower local user populations to whom they transfer responsibilities and rights.

- In conjunction with this, continue to support research and trials into pluralistic systems of co-management that really do function effectively and equitably, and forest management techniques that deliver greater benefits to poorer users.

A final point is to note that changes in participatory forestry have sometimes been promoted, by donors, ahead of the capacity of recipient governments and forest departments to implement them. Where this is so, it could be desirable if more attention is now paid to consolidation, moving from promotion to critical analysis, with more consideration of how best to address distributional weaknesses and problems that have arisen. In addition, exaggerated expectations need to be avoided. Just as there is a danger in trying to achieve too much too quickly, so there is also a risk of overloading programmes directed at alleviating poverty through forestry. It is important to recognise the limits to how much change can be achieved within the framework of forest-oriented programmes.

\section{References}

Agrawal, A. and Ostrom, E. 1999 Collective action, property rights, and devolution: a comparative examination of forest and protected area management in India and Nepal. Paper to CGIAR International Workshop on Collective Action, Property Rights and Devolution of Natural Resource Management. Puerto Azul, the Philippines, 21-25 June 1999.

Agrawal, A. and Ribot, J. 1999 Accountability in decentralization: a framework with South Asian and West African cases. Journal of Developing Areas 33: 473-502

Arnold, J.E.M. Forthcoming. Forests and People: Twenty-five Years of Community Forestry. FAO, Rome.

Arnold, J.E.M. and Dewees P.A. (eds.). 1997 Farms, Trees and Farmers: Responses to Agricultural Intensification. Earthscan Publications, London. (Also published as Tree Management in Farmer Strategies: Responses to Agricultural Intensification. Oxford University Press, Oxford, 1995.)

Arnold, J.E.M., Liedholm, C., Mead, D. and Townson, I.M. 1994 Structure and Growth of Small Enterprises using Forest Products in Southern and Eastern Africa. O.F.I Occasional Papers No. 47. Oxford Forestry Institute, Oxford and GEMINI Working Paper No. 
48. Growth and Equity through Microenterprise Investments and Institutions, Bethesda.

Beer, J. de and McDermott, M. 1989 The Economic Value of Non-timber Forest Products in Southeast Asia. Netherlands Committee for IUCN, Amsterdam.

Browder, J.O. 1992 The Limits of Extractivism: Tropical Forest Strategies beyond Extractive Reserves. Bioscience 42 (3): 174-182.

Brown, D. 1999 Principles and Practice of Forest CoManagement: Evidence from West-Central Africa. European Union Tropical Forestry Paper 2. ODI, London.

Bruce, J.W. 1999 Legal bases for the management of forest resources as common property. Community Forestry Note 14. FAO, Rome.

Byron, N. and Arnold, M. 1999 What Futures for the People of the Tropical Forests? World Development 27 (5): 789-805.

Campbell, J.G. 1990 Whose land is this? Overlapping tenure, tenure transitions, tenure options and tenurial technology in India's common property resources. Paper to the First Conference of the International Association for the Study of Common Property, Durham, USA, 27-30 September 1990.

Carney, D. (ed.) 1998 Sustainable Rural Livelihoods: What contribution can we Make? Department for International Development, London.

Cavendish, W. 2000 Rural livelihoods and non-timber forest products. Centre for the Study of African Economies, Oxford, and Imperial College, London.

Current, D., Lutz, E. and Scherr, S. 1995 Adoption of Agroforestry. In: Current, D., Lutz, E., and Scherr, S. (eds.) Costs, Benefits and Farmer Adoption of Agroforestry, 1-27. World Bank Environment Paper 114. World Bank, Washington.

Dewees, P.A. 1997 Farmer responses to tree scarcity: the case of woodfuel. In: Arnold, J.E.M. and Dewees, P.A. (eds.) Farms, Trees and Farmers: Responses to Agricultural Intensification, 174-197. Earthscan Publications, London.

Dewees, P.A. and Scherr, S.A. 1996 Policies and markets for non-timber tree products. EPTD Discussion Paper 16. International Food Policy Research Institute, Washington.

Dove, M.R. 1993 A revisionist view of tropical deforestation and development. Environmental Conservation 20 (1): 17-24.

Douglas, J.J. 1983 A Re-Appraisal of Forestry Development in Developing Countries. Martinus Nijhoff W. Junk., The Hague.

Evans, M. I. 1993 Conservation by Commercialization. In: Hladick, C.M., Hladick, A., Linares, O.F., Pagezy, H. Semple, A. and Hadley, M. (eds.) Tropical forests, people and food. MAB Series, Vol. 13. UNESCO, Paris.
Falconer, J. 1990 The Major Significance of "Minor" Forest Products: The Local Use and Value of Forests in the West African Humid Forest Zone. Community Forestry Note 6. FAO, Rome.

Falconer, J. and Arnold, J.E.M. 1989 Household Food Security and Forestry: An Analysis of Socioeconomic Issues. Community Forestry Note 1. FAO, Rome.

FAO. 1987 Small-scale Forest Based Processing Enterprises. Forestry Paper 79, FAO, Rome.

FAO. 1995 Report of the International Expert Consultation on Non-Wood Forest Products. NonWood Forest Products 3. FAO, Rome.

FAO. 1999 Pluralism and Sustainable Forestry and Rural Development. Proceedings of an international workshop, Rome, 9-12 December 1997.

Fisher, R.J. 1995 Collaborative Management of Forests for Conservation and Development. Issues in Forest Conservation. IUCN/WWF.

Forsyth, T. and Leach, M. with Scoones, I. 1998 Poverty and environment: priorities for research and policy, an overview study. Prepared for the UNDP and European Commission, Institute of Development Studies, Brighton.

Freese, F. 1996 The commercial, consumptive use of wild species: managing it for the benefit of biodiversity. WWF Discussion Paper. WWF, Washington.

Halladay, P. and Gilmour, D.A. (eds.) 1995 Conserving Biodiversity Outside Protected Areas: The Role of Traditional Agro-ecosystems. The IUCN Forest Conservation Programme. IUCN, Gland, Switzerland.

Hazell, P. and Reardon, T. 1998 Interactions among the rural nonfarm economy, poverty, and the environment in resource-poor areas. Paper prepared for IFPRI Conference on Strategies for Stimulating Growth of the Rural Nonfarm Economy in Developing Countries. Airlie House, Virginia, 17-21 May 1998.

Hill, I. and Shields, D. 1998 Incentives for Joint Forest Management in India: Analytical Methods and Case Studies. World Bank Technical Paper No. 394. World Bank, Washington.

Hobley, M. 1996 Participatory forestry: The process of change in India and Nepal. Rural Development Forestry Study Guide. Overseas Development Institute.

Leach, M. and R. Mearns. 1996 Environmental change and policy: challenging received wisdom in Africa. In: Leach, M. and Mearns, R. (eds.) Lie of the Land: Challenging Received Wisdom on the African Environment. The International African Institute/ James Currey, Oxford.

Liedholm, C. and Mead, D.C. 1993 The Structure and Growth of Microenterprises in Southern and Eastern Africa. GEMINI Working Paper No. 36. GEMINI Project, Bethesda, USA. 
Mayers, J. 2000 Company-community forestry partnerships: a growing phenomenon. Unasylva 50 (1): 33-41.

Mellor, J.W. 2000 Agricultural growth, rural employment, and poverty reduction — non-tradables, public expenditure, and balanced growth. Paper prepared for World Bank Rural Week 2000.

Neumann, R.P. 1996 Forest products research in relation to conservation policies in Africa. In: Ruiz Pérez, M. and Arnold, J.E.M. (eds.) Current issues in non-timber forest products research. CIFOR/ODA, CIFOR, Bogor.

Noordwijk, M. van, Tomich, T.P., Foresta, H. de, and Michon, G. 1997 To segregate-or to integrate. Agroforestry Today January-March 1997.

Plotkin, M. and Famolare, L. 1992 Preface In: Plotkin, M. and Famolare, L. (eds.) Sustainable Harvest and Marketing of Rain Forest Products. Island Press, Washington.

Ribot, J.C. 1999 Decentralization, participation and accountability in Sahelian forestry: legal instruments of political administrative control. Africa 69 (1).

Saxena, N.C. 1992 Adoption and Rejection of Eucalyptus on Farms in North-West India. DPhil Dissertation, University of Oxford. (Published, 1994, as India's Eucalyptus Craze: The God that Failed. Sage Publications, New Delhi.)

Sayer, J. 2000. Exploding the myths of deforestation. The Asian Wall Street Journal, 24 January.

Simula, M. and Ghazali, B.H. 1996 Timber certification in transition. Tropical Forest Update 6 (4): 20-22.

Taylor, P.L. and Zabin, C. 2000 Neoliberal reform and sustainable forest management in Quintana Roo, Mexico: rethinking the institutional framework off the Forestry Pilot Plan. Agriculture and Human Values 17 (2): 141-156.

Townson, I.M. 1995 Forest Products and Household Incomes: A Review and Annotated Bibliography. Tropical Forestry Papers 31. Centre for International Forestry Research and Oxford Forestry Institute, Oxford.

Vira, B., Dubois, O., Daniels, S.E. and Walker, G.B. 1998 Institutional pluralism in forestry: considerations of analytical and operational tools. Unasylva Vol. 49 No. 194.

Wells, M. and Brandon, K. with Hannah, L. 1992 People and Parks: Linking Protected Area Management with Local Communities. World Bank/WWF/USAID, World Bank, Washigton.

Westoby, J.C. 1962. The role of forest industries in the attack on under-development. The State of Food and Agriculture 1962, FAO. (Reprinted in J.C. Westoby, "The Purpose of Forests", Blackwell, 1987)
Westoby, J.C. 1978. Forest industries for socio-economic development. Commonwealth Forestry Review 58 (2): 107-116. (Reprinted in Westoby, J.C. 1987 The Purpose of Forests. Blackwell).

World Bank. 2000 A Review of the World Bank's 1991 Forest Strategy and its Implementation, Volume I: Main Report. Operations Evaluation Department, World Bank, Washington (Preliminary Report, January 13, 2000).

Wunder, S. 2001 Poverty alleviation and tropical forests-what scope for synergies? World Development 29 (11), November. 